\title{
Ecological Risk Index and Their Associated Health Risk Evaluation of Toxic Heavy Metals in Cultivated Vegetable and Cereal in Different Peri-Urban Regions of an Indian Metropolitan City, Lucknow
}

\section{Pradeep Kumar}

Babasaheb Bhimrao Ambedkar University

\section{Dipti Rawat}

Babasaheb Bhimrao Ambedkar University

\section{Sunil Kumar}

National Environmental Engineering Research Institute CSIR

Rana Pratap Singh ( $\nabla$ rpsingh@bbau.ac.in )

Babasaheb Bhimrao Ambedkar University

\section{Research Article}

Keywords: Carcinogenic Risk Factor (CR's), Contamination coefficient (ifC), Ecological risk factor (ifE), Ecological risk index (ERI), Phytoaccumulation factor (PF), and Toxic heavy metal (THMs).

Posted Date: June 4th, 2021

DOl: https://doi.org/10.21203/rs.3.rs-503257/v1

License: (c) (1) This work is licensed under a Creative Commons Attribution 4.0 International License. Read Full License 
1 Ecological Risk Index and their Associated Health Risk Evaluation of Toxic Heavy Metals

2 in cultivated vegetable and cereal in different peri-urban regions of an Indian metropolitan

3 city, Lucknow

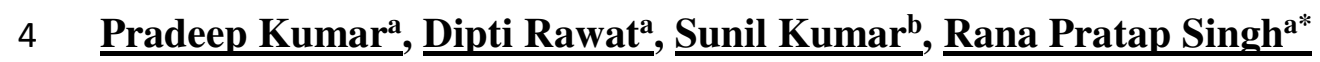

5 a Department of Environmental Science, Babasaheb Bhimrao Ambedkar (A Central) University,

6 Vidya Vihar, Raebareli road, Lucknow, U.P-226025, India.

$7 \quad{ }^{\mathrm{b}}$ Technology Development Center, CSIR-National Environmental Engineering Research Institute

8 (NEERI), Nehru Marg, Nagpur, Maharashtra-440020, India.

$9 \quad$ *Corresponding Author

10 Rana Pratap Singh, Department of Environmental Science, Babasaheb Bhimrao Ambedkar (A

11 Central) University, Vidya Vihar, Raebareli road, Lucknow, U.P-226025, India

12 E-mail: rpsingh@bbau.ac.in / dr.ranapratap59@gmail.com

\section{HIGHLIGHTS}

$\checkmark$ The level of toxic heavy metals in agricultural soil, irrigation water, and different parts of vegetables and cereals are determined periodically from peri-urban regions of a metropolitan city Lucknow, India; a city with 3.7 million populations.

$\checkmark$ The level of toxic heavy metals e.g. As and $\mathrm{Pb}$ were found significantly higher in the edible part of vegetable and cereal samples collected from different agricultural areas.

$\checkmark$ In this study, we found that the phytoaccumulation factor of $\mathrm{Cd}$ and $\mathrm{Ni}$ was significantly higher in the edible parts of crop plants via irrigation water as compared to the agricultural soil.

$\checkmark$ The carcinogenic health risk of $\mathrm{Cr}$, As, $\mathrm{Cd}$, and $\mathrm{Ni}$ on consumers was significantly higher even when present in low concentration in the edible parts of crop plants.

\section{ABSTRACT}

The present study investigates the phytoaccumulation factor (PF), Ecological risk index ( $E_{R I}$, and carcinogenic risk factor (CRs) of toxic heavy metals $\left(\mathrm{THM}_{\mathrm{s}}\right.$ ) i.e. $\mathrm{As}, \mathrm{Cd}, \mathrm{Cr}, \mathrm{Pb}$, and $\mathrm{Ni}$ in the agricultural soil, irrigation water, vegetables and cereals samples collected from peri-urban regions of Lucknow. The level of these metals was within the maximum allowable concentration (MAC) (FAO/WHO 2011) in agricultural soil while it was higher in irrigation water. The phytoaccumulation factor of $\mathrm{Cd}$ and $\mathrm{Ni}$ was very high in the edible parts of vegetable and cereal samples which show that they might have entered through metal-contaminated irrigation water 
even if not available in the soil. The contamination coefficient $\left({ }_{f}^{i} C\right)$ and Ecological risk factor $\left({ }_{f}^{i} E\right)$ of metals was detected in the range of low risk in all agricultural soil, whereas Ecological risk index of metals was found in the moderate risk which indicated a mild impact on the agroecosystem. The carcinogenic risk potential of metals was found more than the requisite value of $10^{-4}$ in tomato, spinach, and wheat samples. This study indicates that the metals possess a moderate ecological risk and high carcinogenic risk potential through the consumption of metalcontaminated vegetables and cereals grown and sold in peri-urban regions and food markets.

Keywords: - Carcinogenic Risk Factor (CR's), Contamination coefficient $\left({ }_{\mathrm{f}}^{\mathrm{i}} \mathrm{C}\right)$, Ecological risk factor $\left({ }_{\mathrm{f}}^{\mathrm{i}} \mathrm{E}\right)$, Ecological risk index $\left(\mathrm{E}_{\mathrm{RI}}\right)$, Phytoaccumulation factor $(\mathrm{PF})$, and Toxic heavy metal $\left(\mathrm{THM}_{\mathrm{s}}\right)$.

\section{INTRODUCTION}

42 Carcinogenic impact of heavy metal contamination in food systems is considered as a major cause of potentially growing environmental and human health concerns throughout the world (Rehman et al., 2017). The $\mathrm{THM}_{\mathrm{s}}$ enter in the environment from anthropogenic as well as natural activities (Figure 1) (Oti, 2015; Waqas et al., 2015). During irrigation of crops, with the heavy metal contaminated water it may get accumulated and may enter into the plants cultivated in the vicinity, which increases the potential risk to the environment and human health (Zhiyuan et al., 2011). Vegetable crops provide major nutritional components of the human and animal diet and a rich source of carbohydrate, vitamins, minerals, fiber and cereals are used as stable food for the people (Hu et al., 2013). The absorption of $\mathrm{THM}_{\mathrm{s}}$ by the vegetable and cereal plants roots can be resulted in accumulation at high level in its various parts even present in low levels in the soil (Jolly et al., 2013). Therefore, consumption of toxic metals through the food chain is considered a major source of toxic metals contamination in humans and livestock which causes many known and unknown diseases including cancers, gastrointestinal disorders, and neurological problems. The leafy vegetables have been reported to be more prone to absorb, transport, and accumulate toxic heavy metal in its edible parts than other vegetables (Zhou et al., 2016; Rehman et al., 2017). Associated health hazard assessment for $\mathrm{THM}_{\mathrm{s}}$ in the human population can provide an assessment of the real survival threat to the people consuming heavy metal contaminated food items (Kooner et al., 2014). Ingestion of toxic metals through food will cause its accumulation in the cells of the consumer organisms, producing serious health concern (Sathawara et al., 2004). Arsenic (As) is associated with abortion, stillbirths, and cardiovascular complications whereas, Lead $(\mathrm{Pb})$ can 
adversely affect the mental development of children. The extreme $\mathrm{Pb}$ in the blood can induce kidney and liver disfunction, nephropathy, cardiovascular diseases, nervous system disfunction, hypertension, bone diseases, and disorders of the immune and reproductive systems (Khan et al., 2012; Njuguna et al., 2019; Zwolak et. al., 2019).

Few studies are focused on $\mathrm{Pd}, \mathrm{Ni}, \mathrm{Cr}$, As and $\mathrm{Cd}$ contaminated soil and vegetable species with low heavy metal accumulation (Zhou et at, 2016; Alghobar and Suresha 2017; Adimalla et al., 2018; Kumar et al, 2019). Chabukdhara et al., (2016) have been reported that the vegetable grown around the pre urban and urban industrial area in Ghaziabad city, India has high metal concentration and possess potential health risks to the consumers. Recently Ratnakar et al., (2019) have also reported that the co-contamination of toxic metal i.e., $\mathrm{Pb}, \mathrm{Cr}, \mathrm{Ni}, \mathrm{Fe}, \mathrm{Cu}, \mathrm{Cd}$, As and $\mathrm{Mn}$ in agriculture land located nearly the industrial area around Lucknow, India is present in high concentration especially in case of $\mathrm{Cr}$ and Cd. Likewise, Kumar et al., (2019) have also reported the high contamination of $\mathrm{Fe}, \mathrm{Cu}, \mathrm{Cr}$ and $\mathrm{Cd}$ in $32 \%$ vegetable samples collected from the periurban areas of Lucknow. On other hand according to Chen et al., (2020), the direct application of Phosphate fertilizer in the range of $1-400 \mathrm{~kg} / \mathrm{ha}^{-1}$ would not lead to straight contamination risk of $\mathrm{Zn}, \mathrm{Cu}, \mathrm{Cd}, \mathrm{Pb}, \mathrm{Cr}, \mathrm{Ni}$, and $\mathrm{As}$ in agricultural soil and wheat Grains. The contamination level of THMs in vegetables and cereal in cultivated areas of the peri-urban regions of highly populated areas are available but their place of origin and assessment of its Ecological risk potential and carcinogenic potential along with the other health impacts on the urban consumers have not been previously reported in these peri-urban regions. In this study we have attempted to trace a relationship between the metal levels in the irrigated water, agricultural soil and the vegetables and cereals grown in the vicinity of Lucknow, India and the main objective of this study is to investigate the pathway of toxic metals contamination in cultivation chain and phytoaccumulation of $\mathrm{As}, \mathrm{Pb}, \mathrm{Ni}, \mathrm{Cr}$, and $\mathrm{Cd}$ in the edible parts of the different vegetable and cereals plants and assess the probable ecological risk using the Ecological risk index ( $\left.E_{R I}\right)$ and associated health hazards via consumption of vegetable and cereal on population residing in the vicinity of the study area.

\section{METHOD AND METHODOLOGY}

\subsection{Sampling Area and sample preparation}

Total 210 samples of agricultural soil, irrigation water as well as vegetable and cereal (Solanum lycopersicum (Tomato); Spinacia oleracea (Spinach); and Triticum aestivum (Wheat)) samples were collected from various peri-urban agriculture areas from Biswan, Shindholi, Pasonda, 
Khairabaad, and Mohanlal Ganj at different time intervals (i.e., September to December 2018 and June to September 2019). The time and frequency of sampling were selected simultaneously according to the availability of seasonable vegetables in different vegetable markets in Lucknow, India. From each sampling site, a composite of at least 9 samples $(1 \mathrm{~kg} / \mathrm{sample})$ for each sample was collected. Agricultural soil, vegetable, and cereal samples were collected in clean PVC

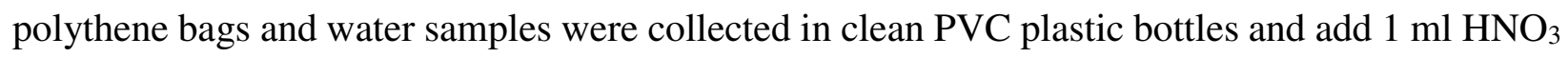
per liter of water sample for preservation of the heavy metal content in irrigation water. Firstly, the collected vegetable samples were washed using tap water to remove dust and atmospheric deposition and cut into small pieces with the help of a sharp object. After that, the agricultural soil, vegetable and cereal samples were oven-dried at $65^{\circ} \mathrm{C}$ until a constant weight was not achieved. A commercial blender was used to grind the samples which were homogenized by sieving before acid digestion.

One gram of the dry powdered agriculture soil as well as the vegetable and cereal samples were digested in aqua- mixture $\left(15 \mathrm{ml}, 70 \%\right.$ Conc. $\mathrm{HNO}_{3}$ and $\left.65 \% \mathrm{HClO}_{4} ; 2: 1\right)$ and $50 \mathrm{ml}$ of irrigation water with $5 \mathrm{ml}$ of Conc. $\mathrm{HNO}_{3}$ at $80^{\circ} \mathrm{C}$ until the transparent solution was achieved and cooled at room temperature. Thereafter the solution was diluted up to $50 \mathrm{ml}$ using distilled and deionsed water (Allen et al., 1986). The detection of $\mathrm{As}, \mathrm{Cd}, \mathrm{Ni}, \mathrm{Cr}$ and $\mathrm{Pb}$ was done in the digested samples through Inductive Coupled Plasma Optical Emission Spectroscopy (ICP-OES, modelICAP 6300/DUO and Manufactured by Thermo fisher).

\subsection{Phytoaccumulation factor (PF)}

The Phytoaccumulation factor (PF) was calculated in various parts (root, stem, fruits and grains) of vegetable and cereal samples (dry weight basis) by using the following formulas: -

$$
P F=M_{c}(\text { plant }) / M_{s}(\text { soil })
$$

Where $M_{c}$ (plant) represents the concentration of heavy metals present in the different parts of crop plant (stem/root/edible parts) and $M_{s}($ soil) represent the metal concentration present in agriculture soil respectively. Phytoaccumulation factor is also known as bioaccumulation factor, uptake factor, and concentration factor, for calculating the accumulation capacity of toxic metals from soil and irrigation water to different parts of crop plants (Zeng et al., 2015). 


\subsection{Ecological risk index $\left(E_{R I}\right)$}

The ERI was calculated as the sum of individual ecological risk factor $\left({ }_{r}^{i} E\right)$ for evaluating the toxicity of heavy metal in sediments and has been calculated extensively applied to the soil (Liang et al., 2015; Adimalla and Wang, 2018).

In this study $\mathrm{E}_{\mathrm{RI}}$ was calculated by the following equations: -

$$
\begin{aligned}
& \left({ }_{f}^{i} C\right)=\mathrm{M}_{\mathrm{n}} / \mathrm{M}_{\mathrm{br}} . \\
& \left({ }_{r}^{i} E\right)={ }_{r}^{i} T *{ }_{f}^{i} C . \\
& \mathrm{E}_{\mathrm{RI}}=\sum\left({ }_{r}^{i} E\right) \ldots .
\end{aligned}
$$

Where ${ }_{f}^{i} C$ is the contamination coefficient of an individual metal; $\mathrm{M}_{\mathrm{n}}$ is the toxic metal level present in the soil; $\mathrm{M}_{\mathrm{br}}$ is the background value for metal; ${ }_{r}^{i} E$ is the Ecological risk index for single metal; ${ }_{r}^{i} T$ is the toxicity factor for single toxic metal introduced by Hakenson (1980). The ${ }_{r}^{i} T$ value of $\mathrm{As}, \mathrm{Pb}, \mathrm{Cd}, \mathrm{Ni}$ and $\mathrm{Cr}$ are 10, 5, 30, 2 and 5, respectively. The background concentration of toxic heavy metal of $\mathrm{As}, \mathrm{Cd}, \mathrm{Pb}, \mathrm{Ni}$ and $\mathrm{Cr}$ are 13.37, 0.3, 12.5, 20 and 90. The ERI was classified in five stages according to the value of ${ }_{f}^{i} C,{ }_{r}^{i} E$ and $E_{R I}$ (Table 1) (Hakenson, 1980; Adimalla, 2018; Wang et al., 2018).

\subsection{Associated health risk assessment for vegetable consumption}

The fate of carcinogenicity was calculated in terms of the Carcinogenic risk factor (CRs). The level of the toxic metal in crop plants is used to calculating the Carcinogenic Risk factor (CR's).

\subsubsection{Carcinogenic risk factor (CR's)}

The CRs is a dimensionless and used to calculate the carcinogenic risk (lifetime cancer risk) by using the USEPA Region III risk-based concentration table method.

$$
C R^{\prime} S=\frac{M c * I R * 10^{-3} * C P S O * E F * E D}{B W * A T C}
$$

Where; $\mathrm{Mc}=$ metal concentration in edible part of crop plants, $\mathrm{IR}=$ Ingestion rate of vegetables in gram per day (e.g., $130 \mathrm{~g} /$ day), $\mathrm{BW}=$ Average body weight (e.g., $65 \mathrm{~kg}$ ), EF= Exposure frequency (365 days/year), ED= Exposure duration (70 years) (life expectory of male approx. 69 years and

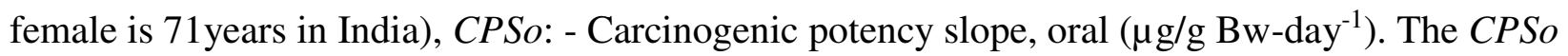
value of $\mathrm{Cr}, \mathrm{Cd}$, As and $\mathrm{Pb}$ is $0.5,15,1.5$ and $8.5 \times 10^{-3}$ (USEPA; United State Environmental Protection Agency 2015), ATc: - Average time for carcinogens (365 days/year $\times$ ED). 


\subsection{Statistical Analysis}

The Experimental data were tested for significance by One-way- ANNOVA followed by the Duncan's test at significant level of $5 \%(\mathrm{p}<0.05)$ using the statistical analysis software SPSS version 20.0 and Microsoft excel 2007. The data are presented in a means of three replicates with standard error.

\section{RESULTS}

\subsection{Toxic metals levels in irrigation water, agriculture soil as well as in vegetable and cereal} sample.

The level of $\mathrm{Cd}, \mathrm{Cr}, \mathrm{As}, \mathrm{Ni}$, and $\mathrm{Pb}$ was found in the range of 0.15-8.10 $\mu \mathrm{g} / \mathrm{ml}, 0.082-1.473 \mu \mathrm{g} / \mathrm{ml}$, $0.004-40.47 \mu \mathrm{g} / \mathrm{ml}, 2.17-49.37 \mu \mathrm{g} / \mathrm{ml}$, and $0.004-64.31 \mu \mathrm{g} / \mathrm{ml}$ respectively in the irrigation water used to cultivate the vegetable and cereal. The concentrations were significantly higher than the maximum allowable concentration (MAC) (Figure 2) except the As in tubewell water from Pasonda; $\mathrm{Cr} \& \mathrm{Cd}$ in canal water from Biswan and Shindholi; $\mathrm{Cr}$ in Tubewell water from Shindholi and Khairabaad.

The level of $\mathrm{THM}_{\mathrm{s}}$ in agricultural soil samples are summarized in Figure 2. The observed concentrations range of $\mathrm{As}, \mathrm{Pb}, \mathrm{Ni}, \mathrm{Cr}$, and $\mathrm{Cd}$ in agricultural soil samples were 0.39-56.35 $\mu \mathrm{g} / \mathrm{g}$, $1.04-352.62 \mu \mathrm{g} / \mathrm{g}, 0-418.57 \mu \mathrm{g} / \mathrm{g}, 5.145-209.0 \mu \mathrm{g} / \mathrm{g}$, and $0.82-87.34 \mu \mathrm{g} / \mathrm{g}$ which were significantly lower than the MAC except $\mathrm{Pd}, \mathrm{Cr}, \mathrm{Ni} \& \mathrm{Cd}$ content in wheat cultivated soil from Biswan, Shindholi and Khairabaad, $\mathrm{Pb} \& \mathrm{Ni}$ content in tomato cultivated soil from Shindholi, Pasonda, Khairabaad and Mohanlal Ganj. Pb, Cd \&Ni content in Spinach cultivated soil from Pasonda and Mohanlal Ganj showed higher value more than MAC.

The level of $\mathrm{THM}_{\mathrm{s}}$ in vegetable and cereals are showed in Figure 2. The $\mathrm{THM}_{\mathrm{s}}$ concentration of $\mathrm{As}, \mathrm{Ni}, \mathrm{Cr}, \mathrm{Pb}$, and $\mathrm{Cd}$ in vegetable and cereal plants were found in the range of $37.72-2392.05 \mu \mathrm{g} / \mathrm{g}, 29.13-82.62 \mu \mathrm{g} / \mathrm{g}, 7.14-215.02 \mu \mathrm{g} / \mathrm{g}, 2.45-9.23 \mu \mathrm{g} / \mathrm{g}$, and 38.56-503.86 $\mu \mathrm{g} / \mathrm{g}$ in Solanum lycopersicum (Tomato); 33.08-50.36 $\mu \mathrm{g} / \mathrm{g}, 32.95-65.39 \mu \mathrm{g} / \mathrm{g}, 9-84.82 \mu \mathrm{g} / \mathrm{g}, 0.55-5$ $\mu \mathrm{g} / \mathrm{g}$, and 8.75-267.56 $\mu \mathrm{g} / \mathrm{g}$ in Triticum aestivum (Wheat) and 13.73-60.45 $\mu \mathrm{g} / \mathrm{g}, 19.96-66.52 \mu \mathrm{g} / \mathrm{g}$, $19.58-122.30 \mu \mathrm{g} / \mathrm{g}, 1.66-18.99 \mu \mathrm{g} / \mathrm{g}$, and $5.90-48.54 \mu \mathrm{g} / \mathrm{g}$ in Spinacia oleracea (Spinach) significantly higher than the MAC 
3.2 Toxic metal concentration in various part of vegetable and cereal plants (root, stem and edible parts) samples

The concentration of $\mathrm{THM}_{\mathrm{s}}(\mathrm{Cd}, \mathrm{As}, \mathrm{Cr}, \mathrm{Pb}$, and $\mathrm{Ni})$ content in various parts of vegetable and cereal plants is presented in Figure 3. The clear differences in the levels of the toxic metals can be seen in figure 3 . The mean concentration of $\mathrm{THM}_{\mathrm{s}}(\mathrm{Cd}, \mathrm{As}, \mathrm{Ni}, \mathrm{Pb}$, and $\mathrm{Cr})$ in vegetable and cereals plant roots were found greater than the MAC in all samples collected from the agricultural field of various peri-urban areas around Lucknow city. The observed concentrations of $\mathrm{Cd}, \mathrm{As}, \mathrm{Ni}, \mathrm{Pb}$, and $\mathrm{Cr}$ in vegetable and cereal plants root ranged from $0.378-18.46 \mu \mathrm{g} / \mathrm{g}, 7.40-66.30 \mu \mathrm{g} / \mathrm{g}, 0-466 \mu \mathrm{g} / \mathrm{g}$, $0.519-150.9 \mu \mathrm{g} / \mathrm{g}$, and $0.177-85.7 \mu \mathrm{g} / \mathrm{g}$ respectively; on a dry weight basis.

Figure 3 summarizes the data of selected $\mathrm{THM}_{\mathrm{s}}$ in stem portion of vegetable and cereal plants. The mean concentrations of $\mathrm{THM}_{\mathrm{s}}$ (e.g., $\mathrm{Pb}, \mathrm{As}, \mathrm{Cr}$, and $\mathrm{Ni}$ ) in stem were found greater than the MAC except Cd in tomato stem $(0.04 \mu \mathrm{g} / \mathrm{g})$ from Shindholi. The observed ranges of THM levels of $\mathrm{Ni}, \mathrm{As}, \mathrm{Cd}, \mathrm{Pb}$, and $\mathrm{Cr}$ in stem portion were 0.94-15.19 $\mu \mathrm{g} / \mathrm{g}, 11.25-24.73 \mu \mathrm{g} / \mathrm{g}, 0.04$ $7.61 \mu \mathrm{g} / \mathrm{g}, 0.94-15.19 \mu \mathrm{g} / \mathrm{g}$, and 2.26-27.80 $\mu \mathrm{g} / \mathrm{g}$ respectively.

The level of $\mathrm{Ni}, \mathrm{Pb}, \mathrm{Cd}, \mathrm{Cr}$ and As were also detected in the edible parts of crop collected from different agricultural area, i.e. Salanum lycopersicum (tomato), Spinacia oleracea (Spinach), and Triticum aestivum (Wheat) are presented in figure 3 which shows higher concentration than the MAC except $\mathrm{Cd}$ in wheat from all sampling sites and spinach from Biswan. The observed concentration range of $\mathrm{Pb}, \mathrm{As}, \mathrm{Ni}, \mathrm{Cr}$ and $\mathrm{Cd}$ metal in the edible parts were 1.91-23.22 $\mu \mathrm{g} / \mathrm{g}, 0.19$ $18.67 \mu \mathrm{g} / \mathrm{g},-22.02-50.68 \mu \mathrm{g} / \mathrm{g}, 5.06-46.92 \mu \mathrm{g} / \mathrm{g}$ and $0.01-1.65 \mu \mathrm{g} / \mathrm{g}$ respectively. The $\mathrm{THM}_{\mathrm{s}}$ concentrations in edible parts of vegetable and cereal plants from different Agricultural areas were decreased in the order of $\mathrm{Ni}>\mathrm{Cr}>\mathrm{As}>\mathrm{Pb}>\mathrm{Cd}$ for Biswan and Khairabaad; $\mathrm{Ni}>\mathrm{Cr}>\mathrm{Pb}>\mathrm{As}>\mathrm{Cd}$ for Pasonda; $\mathrm{Ni}>\mathrm{Pb}>\mathrm{Cr}>\mathrm{As}>\mathrm{Cd}$ for Shindholi; and $\mathrm{Ni}>\mathrm{Cr}>\mathrm{Pb}>\mathrm{As}>\mathrm{Cd}$ for Mohanlal Ganj, Lucknow.

\subsection{Phytoaccumulation factor (PF) in crop plant through agricultural soil and irrigation} water.

PF is a significant indicator of the metal accumulating capability of plants through agricultural soil as well as irrigation water. Phytoaccumulation defined as the ratio of the toxic metal's concentration in the various parts of vegetable and cereal plants to the $\mathrm{THM}_{\mathrm{s}}$ concentration in the soil and irrigation water (Zhou et al., 2016). The PF of $\mathrm{THM}_{\mathrm{s}}$ in vegetable and cereal plants are presented in table 2. PF calculated by using equation no. 1 and the PF value above the 1 for the $\mathrm{THM}_{\mathrm{s}}$ in vegetable and cereals is considered dangerous for the human and animal health (Singh et 
al., 2010). The range of $\mathrm{PF}$ of $\mathrm{Cr}, \mathrm{As}, \mathrm{Ni}, \mathrm{Cd}$, and, $\mathrm{Pb}$ in vegetable and cereal plants samples through agriculture soil were $0.12-32.15,0.58-620.38,0.26-5.80,0.01-7.42$, and $0.31-22.40$ whereas through irrigation water vegetable and cereal plants samples were 0.3-1953.6, 27.8329350.6, 0.58-22.39, 0.14-4617.01 and 2.25-3.4.92 which were significantly higher than the tolerance limit. Our study reveals/ concludes that the ability of Phytoaccumulation of $\mathrm{THM}_{\mathrm{s}}$ in vegetable and cereal plants through irrigation water is much higher than the ability of phytoaccumulation of $\mathrm{THM}_{\mathrm{s}}$ in crop plants through the agriculture soil.

\subsection{Phytoaccumulation factor (PF) in various parts of vegetable and cereal plants (root, stem} and edible parts) via agricultural soil and irrigation water.

Significant differences were found in the $\mathrm{PF}$ value of $\mathrm{Pb}, \mathrm{As}, \mathrm{Cd}, \mathrm{Cr}$ and $\mathrm{Ni}$ metal in all parts of vegetable and cereal plants (root, Stem and edible parts) through agricultural soil and irrigation water (Table 3 and 4).The $\mathrm{PF}$ of $\mathrm{Pb}, \mathrm{Ni}$, and $\mathrm{Cd}$ were found below the tolerable limit $1(<1)$ as compare to As and $\mathrm{Cr}$ metal in all parts of vegetable and cereal plants samples except $\mathrm{Cd}$ in all vegetable and cereal plants roots via agricultural soil whereas the $\mathrm{PF}$ of $\mathrm{Pb}, \mathrm{As}, \mathrm{Ni}, \mathrm{Cr}$ and $\mathrm{Cd}$ were found much higher than the tolerable limit 1(>1) in different parts of vegetable and cereal plants via the irrigation water respectively. The $\mathrm{PF}$ value of $\mathrm{As}, \mathrm{Cd}, \mathrm{Pb}, \mathrm{Ni}$ and $\mathrm{Cr}$ in root sample were significantly higher than the other parts of crop plants (Stem and Edible parts). In this study we observed that the PF of $\mathrm{Cd}$ and $\mathrm{Ni}$ metal in different parts of vegetable and cereal plants via irrigation water was much higher than the agriculture soil. Our data indicates that the ability for metal accumulation in the root was higher than the stem and edible parts of vegetables and cereals and the ability of $\mathrm{As}, \mathrm{Cr}$ and $\mathrm{Cd}$ metal accumulation in leafy vegetable were much higher than that for $\mathrm{Pb}$ and $\mathrm{Ni}$ through irrigation of $\mathrm{THM}_{\mathrm{s}}$ contaminated water.

\subsection{Ecological risk index $\left(E_{R I}\right)$ of toxic metal contamination in agriculture soil samples}

The $E_{R I}$ assessment is the toxicity effect of the toxic metal concentration in soil compared with the reference value of toxic metal in the earth's crust. The toxic metal in agricultural soil may cause serious ecological risk and negatively interact with human health via food chain (Santos-Frances et al., 2017). The higher concentration of $\mathrm{THM}_{\mathrm{s}}$ in agriculture soil affects the food quality which ultimately leads the risk of serious human diseases like cancer, kidney, liver damage etc. (Suresh et al., 2012). The $E_{R I}$ was calculated by the above given equation 2 to 4 . The comprehensive result of contamination factor ${ }_{f}^{i} \boldsymbol{C}$, ecological risk factor of individual toxic metal $\left({ }_{r}^{i} \boldsymbol{E}\right)$ and $\mathrm{E}_{\mathrm{RI}}$ of heavy 
metal is listed in the Table 5. The ${ }_{r}^{i} \boldsymbol{E}$ and ERI classified in five categories as low risk, moderate risk, considerable risk, high risk and very high risk.

The contamination factor of $\mathrm{Pb}, \mathrm{As}, \mathrm{Cr}$, and $\mathrm{Ni}$ in all soil sample were considered as a low contamination except As in wheat cultivated soil from Biswan (considerable contamination), Wheat and tomato cultivated soil from Khairabaad (moderate contamination), tomato cultivated soil from Pasonda (moderate contamination) and tomato and spinach cultivated soil from Mohanlal Ganj (moderate contamination); $\mathrm{Cr}$ in wheat cultivated soil from Pasonda (considerable contamination); $\mathrm{Pb}$ in spinach cultivated soil from Biswan (very high contamination), wheat and spinach (moderate contamination) and tomato cultivated soil (very high contamination) from Shindholi, wheat, tomato and spinach cultivated soil from Khairabaad (considerable contamination), Wheat cultivated soil (moderate contamination), tomato and spinach cultivated soil (considerable contamination) from Pasonda; $\mathrm{Ni}$ in spinach cultivated soil from Khairabaad (Very high contamination), wheat cultivated soil from Pasonda, tomato and spinach cultivated soil from Mohanlal Ganj (considerable contamination) whereas Cd was considered to have a very high contamination factor in all soil sample collected from various agricultural areas.

The ${ }_{r}^{i} \boldsymbol{E}$ for $\mathrm{Pb}, \mathrm{Cr}, \mathrm{Ni}$ and $\mathrm{As}$ in all soil samples were considered to have a low risk contamination except As in wheat cultivated soil (moderate contamination risk) and $\mathrm{Pb}$ in spinach cultivated soil (moderate contamination risk) from Biswan; $\mathrm{Pb}$ in tomato cultivated soil (considerable contamination risk) from Shindholi However, Cd metal showed considerable contamination risks to high contamination risks in all soil sample collected from the different agricultural areas from peri-urban area around the Lucknow city. The $\mathrm{E}_{\mathrm{RI}}$ value of all $\mathrm{THM}_{\mathrm{s}}$ in soil sample studied, the contamination level was as follows: in Biswan, all soil sample, present low to moderate potential ecological risk contamination. In Pasonda, all soil samples showed low to considerable potential ecological risk. In Khairabaad, all soil samples showed moderate to high ecological risk. In Shindholi, all soil samples showed low to very high potential ecological risk. In Mohanlal Ganj, all soil samples had a moderate potential ecological risk of contamination.

Furthermore, when considering the $E_{R I}$, the levels of contamination (from low to high) of toxic metals from superficial horizons of soil were as follow: Shindholi>Khairabaad>Pasonda>Biswan> Mohanlal Ganj. 


\subsection{Carcinogenic risk factor (CRs) of heavy metals}

The carcinogenic risk factor (CRs) may promote both the non-carcinogenic and carcinogenic effect depending on many factors like daily intake of heavy metal, body weight of consumer, exposure time and oral carcinogenic risk potential slope (CPSo) of toxic heavy metals. The carcinogenic risk factor (CRs) was calculated using above equation (Eq. 5). The CRs value of $\mathrm{As}, \mathrm{Pb}, \mathrm{Cr}, \mathrm{Cd}$ and $\mathrm{Ni}$ due to exposure from edible parts of vegetable and cereal plants is presented in table 6 . The range value of $\mathrm{CRs}$ of $\mathrm{Pb}, \mathrm{As}, \mathrm{Cr}, \mathrm{Cd}$ and $\mathrm{Ni}$ was 3.25E-05 to 0.0012, 0.0006 to $6.963,0.0087$ to $0.041,0.00042$ to 0.04962 and -0.075 to 0.17502 , respectively. The carcinogenic risk factor (CRs) value of $\mathrm{Cd}, \mathrm{Cr}, \mathrm{As}$, and $\mathrm{Ni}$ were found more than the tolerable limit $(<10-4)$ whereas the value of $\mathrm{Pb}$ was found below the tolerance limit except in tomato and wheat from Khairabaad; spinach from Shindholi; tomato, wheat and spinach from Pasonda and tomato and spinach from Mohanlal Ganj respectively in edible parts samples collected from different agricultural areas suggesting highly potential CRs from $\mathrm{As}, \mathrm{Cr}, \mathrm{Cd}$ and $\mathrm{Ni}$ consumption but less concerning for $\mathrm{Pb}$ in Biswan, Shindholi and Khairabaad region.

\section{DISCUSSION}

The ability of heavy metal uptake and accumulation usually differs in different vegetable species, even among cultivation and verities with the same species (Zhou et al., 2016; Säumel et al., 2016). Yang et al., 2010 reported that the cadmium uptake and accumulation in non-leafy vegetable is less than that in the leafy vegetables. In present study we found significant difference in the toxic metals ( $\mathrm{As}, \mathrm{Cd}, \mathrm{Ni}, \mathrm{Pb}$, and $\mathrm{Cr}$ ) concentration in agricultural soil, irrigation water and different parts of vegetable and cereal plants (root, stem and edible parts). The concentration of $\mathrm{Pb}$ and $\mathrm{As}$ were found 70 to730 times higher and above the MAC in vegetable and cereal plants samples collected from the different agricultural areas. The observed concentration of $\mathrm{THM}_{\mathrm{s}}$ of $\mathrm{Cd}, \mathrm{Pb}, \mathrm{Cr}$, As, and $\mathrm{Ni}$ in all samples were found above the MAC and obvious difference in heavy metal concentration $(\mathrm{Pb}, \mathrm{As}, \mathrm{Ni}, \mathrm{Cr}$ and $\mathrm{Cd})$ was found in the similar vegetable and cereals collected from different agricultural areas in various peri-urban areas around Lucknow, India.

The Phytoaccumulation factor (also known as bioaccumulation factor) from soil to plant is an index for evaluating the transfer potential of toxic metals from soil to plant (Zeng et al., 2015). Some previous study reported that PF of toxic metals from agricultural soil to crop plants and irrigation water to crop plants is a key process for human exposure to $\mathrm{THM}_{\mathrm{s}}$ via the food chain (Onsanit et al., 2010). Our data suggest that the phytoaccumulation ability of crop plant through 
irrigation is much higher than the agricultural soil and PF of $\mathrm{As}, \mathrm{Cd}$, and $\mathrm{Cr}$ have higher mobility from irrigation water and agriculture soil in root, followed by $\mathrm{Pb}$ and $\mathrm{Ni}$. Because of their mobility, the concentration of $\mathrm{As}, \mathrm{Cd}$, and $\mathrm{Cr}$ in soil would pose a major health risk.

The ecological risk index ( $\left.E_{\mathrm{RI}}\right)$ was widely used to calculate the ecological risk caused by $\mathrm{THM}_{\mathrm{s}}$ and their impact to an ecosystem (Mamat et al., 2016; Adimalla and Wang, 2018). The contamination factor of agriculture soil through the $\mathrm{THM}_{\mathrm{s}}$ was found $\mathrm{Cd}>\mathrm{As}>\mathrm{Pb}>\mathrm{Cr}>\mathrm{Ni}$ in Biswan and Shindholi; $\mathrm{Ni}>\mathrm{Cd}>\mathrm{Pb}>\mathrm{Cr}>\mathrm{As}$ in Khairabaad; $\mathrm{Cd}>\mathrm{As}>\mathrm{Pb}>\mathrm{Cr}>\mathrm{Ni}$ in Pasonda and $\mathrm{Cd}>\mathrm{Ni}>\mathrm{As}>\mathrm{Cr}>\mathrm{Pb}$ in Mohanlal Ganj. On the other hand, individual ecological risk factor $\left({ }_{r}^{i} E\right)$ of $\mathrm{THM}_{\mathrm{s}}$ in this study areas were recorded as $\mathrm{Cd}>\mathrm{Pb}>\mathrm{As}>\mathrm{Cr}>\mathrm{Ni}$ in Biswan, Pasonda, Shindholi and Khairabaad and $\mathrm{Cd}>\mathrm{As}>\mathrm{Pb}>\mathrm{Cr}>\mathrm{Ni}$ in Mohanlal Ganj respectively. The overall Ecological risk index (ERI), of the all the study area due to $\mathrm{THM}_{\mathrm{s}}$ contamination was order as Shindholi $>$ Khairabaad $>$ Pasonda $>$ Biswan $>$ Mohanlal Ganj. A similar study conducted by Diami et al., 2016 on $E_{R I}$ and associated health hazards of toxic metals in agricultural soil was observed the $E_{R I}$ in the range of 44 to 128 , which were indicating a low risk.

The carcinogenic risk assessment is based on the carcinogenic risk factor (CRs) method. The carcinogenic risk factor (CRs) value of $\mathrm{As}, \mathrm{Ni}, \mathrm{Cd}$ and $\mathrm{Cr}$ were found more than the tolerance limit $\left(<10^{-4}\right)$ whereas the value of $\mathrm{Pb}$ was found below the tolerance limit in all vegetable and cereal samples collected from different agriculture field suggesting high potential CRs from As, $\mathrm{Cr}, \mathrm{Cd}$ and $\mathrm{Ni}$ consumption but less concerning for $\mathrm{Pb}$. In a previous study, Krishna and Mohan, (2016) were observed that the less carcinogenic risk hazards in adults than children via agricultural surface soil around an industrial area, India. In few other studies, similar results were observed in several other regions of the world (Diami et al., 2016; Adimalla et al., 2018; Narsimha and Ranjitha, 2018; Stevanovic et al., 2018; Zhaoyong et al., 2018; Adimalla and Wang, 2018). According to Rapant et al., (2011) the high health risk levels in form of carcinogenic and noncarcinogenic were observed basically in each area, where high soil contamination of toxic heavy metals has been detected.

\section{CONCLUSION}

The present study presents toxic metals contamination of $\mathrm{Pb}, \mathrm{As}, \mathrm{Cr}, \mathrm{Cd}$ and $\mathrm{Ni}$ in agriculture soil, irrigation water and different parts of crop plants collected from the different agriculture fields of various peri-urban areas near Lucknow city of Uttar Pradesh, India. The heavy metal concentrations in all samples were detected above the permissible limit, $\mathrm{Pb}$ and $\mathrm{As}$ were recorded 
70 to 730 fold higher than the safe limit in tomato, spinach and wheat samples. The accumulation of heavy metal from agricultural soil to various parts of vegetable and cereal plants can have an adverse effect on human health and environmental ecology. According the Phytoaccumulation factor $(\mathrm{PF})$ of $\mathrm{As}, \mathrm{Cr}$ and $\mathrm{Cd}$ are most readily absorbed and accumulated $\mathrm{THM}_{\mathrm{s}}$ in the edible parts of vegetable and cereals plants. The contamination factor ${ }_{f}^{i} \mathrm{C}$, ecological risk factor $\left({ }_{r}^{i} E\right)$ and Ecological risk index $\left(\mathrm{E}_{\mathrm{RI}}\right)$ were found in low to moderate risk category in almost $70 \%$ of the studied samples. The carcinogenic risk factor ( $\mathrm{CRs}$ ) value of $\mathrm{As}, \mathrm{Ni}, \mathrm{Cd}, \mathrm{Pb}$, and $\mathrm{Cr}$ was found more than the tolerance limit $\left(<10^{-4}\right)$ in all vegetable and cereal plants samples collected from different agriculture field suggesting highly potential $\mathrm{CRs}$ from $\mathrm{As}, \mathrm{Cr}, \mathrm{Cd}, \mathrm{Pb}$, and $\mathrm{Ni}$ through the consumption of the toxic metal contaminated vegetables grown in the vicinity of densely populated (Lucknow) city of Uttar Pradesh.

\section{ACKNOWLEDGEMENT}

PK is very grateful to the University Grants Commission (UGC) for a financial support in the form of National Fellowship for Schedule Caste Candidates 2017-18 (NFSC 2017-18).

\section{AUTHORS CONTRIBUTION}

Pradeep Kumar: Investigation, Conceptualization, Methodology, Formal analysis, Validation, Data curation, Writing - original draft. Dipti Rawat: Validation, Data curation, Writing - review \& editing. Sunil Kumar: Writing - review \& editing, Resources. Rana Pratap Singh: Project administration, Supervision, Writing - review \& editing, Resources.

\section{FUNDING}

This research was funded by the University Grants Commission (UGC) in the form of National Fellowship for Schedule Caste Candidates 2017-18 (NFSC 2017-18).

\section{DECLARATION OF COMPETING INTEREST}

The authors declare that they have no known competing financial interests or personal relationships that could have appeared to influence the work reported in this paper.

\section{CONFLICT OF INTEREST}

The author declares no conflict of interest.

\section{DATA AVAILABIITY}

All relevant data are within the paper and its supporting information file 
COMPLIANCE WITH ETHICAL STANDARDS

Ethical Approval: Not applicable

Consent to Participate: Not applicable

Consent of Publish: Not applicable

REFERENCES

$\checkmark$ Adimalla N, Li, p, Qian H. 2018. Evaluation of groundwater contamination for fluoride and nitrate in semi-arid region of Nirmal province, South India: a special Emphasis on human health risk assessment (HHRA). Human Ecology Risk Assessment International Journal. 1-18. DOI: http://doi.org/10.1080/10807039.2018.1460579

$\checkmark$ Adimalla N, Wang H. 2018. Distribution, contamination and health risk assessment of heavy metals in surface soils from northern Telangana, India. Arabian Journal of Geosciences. 11, 684. DOI: http://doi.org/10.1007/s12517-018-4028-y

$\checkmark$ Alghobar MA, Suresha S. 2017. Evaluation of metal accumulation in soil and tomatoes irrigated with sewage water from Mysore city, Karnataka, India. Journal of the Saudi Society of Agriculture Sciences. 16: 49-59.

DOI: https://dx.doi.org/10.1016/j.jssas.2015.02.002

$\checkmark$ Allen SE, Grimshaw HM, Rowland AP. 1986. Chemical analysis. In: Moore, P.D., Chapman, S.B., (Eds), Methods in Plant Ecology. Blackwell Scientific Publication, Oxford, Landon. 285-344.

$\checkmark$ Chabukdhara M, Munjal A, Nema AK, Gupta SK, Kaushal RK. 2015. Heavy metal contamination in vegetables grown around peri-urban and urban-industrial cluster in Ghaziabad, India. Human and Ecological Risk Assessment: An International Journal. 22 (3): 736-752. DOI: https://doi.org/10.1080/10807039.2015.1105723

$\checkmark$ Chen, Xiu-Xiu, Liu, Yu-Min, Zhao, Qing-Yue, Cao, Wen-Qing, Chen, Xin-Ping, 2020. Health risk assessment associated with heavy metal accumulation in wheat after long term phosphorus fertilizer application. Environmental Pollution. 262, 1143-48.

DOI: https://doi.org/10.1016/j.envpol.2020.114348

$\checkmark$ Diami SM, Kusin FM, Madzin Z. 2016. Potential ecological and human health risk of heavy metals in surface soils associated with iron ore mining in Pahang, Malaysia. Environmental Science and pollution research. 23 (20), 21086-21097. 
DOI: http://doi.org/10.1007/s11356-016-7314-9

$\checkmark$ Hakanson L. 1980. An ecological risk index for aquatic pollution control. A sedimentological approach. Water Res. 14 (8), 975-1001. DOI: https://doi.org/10.1016/0043-1354(80)90143-8

$\checkmark \quad \mathrm{Hu}$ j, Wu F, Wu S, Cao Z, Lin X, Wong MH. 2013. Bio accessibility dietary exposure and human risk assessment of heavy metals from markets vegetables in Hong Kong revealed with an in vitro gastrointestinal model. Chemosphere. 91: 455-461. DOI: https://doi.org/10.1016/j.chemosphere.2012.11.066

$\checkmark$ Jolly YN, Islam A, Akbar S. 2013. Transfer of metals from soil to vegetables and possible health risk assessment. Springer plus. 2: 385-391.

DOI: https://doi.org/10.1186/2193-1801-2-385

$\checkmark$ Khan K, Wasserman GA, Liu X, Ahmed E, Parvez F, Slavkovich V, Factor-Litvak P. 2012. Manganese exposure from drinking water and children academic achievement. Neurotoxicology. 35: 91-97.

DOI: https://doi.org/10.1016/j.neuro.2011.12.002

$\checkmark$ Kooner R, Mahajan BVC, Dhillon WS. 2014. Heavy metal contamination in vegetables, fruits, soil and water- a critical review. International Journal of Agriculture, Environment \& Biotechnology. 7(3): 603-612.

DOI: https://doi.org/10.5958/2230-732X.2014.01365.5

$\checkmark$ Krishna AK, Mohan KR. 2016. Distribution, correlation, ecological and health risk assessment of heavy metal contamination in surface soils around an industrial area, Hyderabad, India. Environmental Earth Science. 75 (411).

DOI: http://doi.org/10.1007/s12665-015-5151-7

$\checkmark$ Kumar D, Priyanka, Shukla V, Kumar S, Ram RB, Kumar N. 2019. Metal pollution index and daily dietary intake of metals through consumption of vegetables. International Journal of Environmental Science and Technology.

DOI: https://doi.org/10.1007/s13762-0.19-02594-y

$\checkmark$ Kumar RS, Li X. 2018. Bioaccumulation of heavy metal in fish species from the Meiliang Bay, Taihu Lake, China. Toxicology Reports. 5, 288-295.

DOI: https://doi.org/10.1007/s13762-0.19-02594-y 
Mamat Z, Haximu S, Zhang Z, Aji R. 2016. An ecological risk assessment of heavy metal contamination in the surface sediments of Bosten Lake, northwest China. Environmental Science Pollution Research. 23 (8), 7255-7265.

DOI: https://doi.org/10.1007/s11356-015-6020-3

$\checkmark$ Maurya PK, Malik DS, Yadav KK, Kumar A, Kumar S, Kanyab H. 2019. Bioaccumulation and potential sources of heavy metal contamination in fish species in river Ganga basin: Possible human health risks evaluation. Toxicology Reports. 6, 472-481.

DOI: http://doi.org/10.1016/j.toxrep.2019.05.012

$\checkmark$ Narsimha A, Ranjitha S. 2018. Spatial distribution and seasonal variation in fluoride enrichment in ground water and its associated human health risk assessment in Telangana state, South India. Human Ecology Risk Assessment International Journal. 24, 2119-2132. DOI: http://doi.org/10.1080/10807039.2018.1438176

$\checkmark$ Nazir R, Khan M, Masab M, Rehman H, Rauf N, Shahab S, Ameer N, Sajed M, Ullah M, Rafeeq M, Shaheen Z. 2015. Accumulation of heavy metals (Ni, Cu, Cd, Cr, Pb, Zn, Fe) in the soil, water and plants and analysis of physico-chemical parameters of soil and water collected from Tanda Dam kohat. Journal of Pharmaceutical Sciences and Research. 7(3): 89-97.

$\checkmark$ Njuguna SM, Makokha VA, Yan X, Gituru RW, Wang Q, Wang J. 2019. Health risk assessment by consumption of vegetables irrigated with reclaimed waste water: a case study in Thika (Kenya). Journal of Environmental Management. 231: 576-581.

DOI: https://doi.org/10.1016/j.envman.2018.10.088

$\checkmark$ Onsanit S, Ke C, Wang X, Wang KJ, Wang WX. 2010. Trace element in two marine fish culture in fish cages in Fujian province, China. Environmental Pollution. 158, 1334-1342. DOI: https://doi.org/10.1016/j.envpol.2010.01.012

$\checkmark$ Oti W.JO. 2015. Pollution indices and bioaccumulation factors of heavy metals in selected fruits and vegetables from a derelict mine and their associated health implications; International journal of environmental science and toxicology research. 3(1) 9-15. DOI: https://doi.org/10.24102/ijes.v4i1.548

$\checkmark$ Rai PK, Lee SS, Zhang M, Tsang YF, Kim Ki-Hyun. 2019. Heavy metal in food crops: Health risk, fate, mechanisms and management. Environment International. 125, 365-385. DOI: https://doi.org/10.1016/j.envint.2019.01.067 
$\checkmark$ Rapant S, Fajcikova K, Khun M, Cveckova V. 2011. Application of health risk assessment method for geological environment at national and regional scales. Environmental Earth Science. 64, 513-521. DOI: http://doi.org/10.1007/s12665-010-0875-X

$\checkmark$ Rehman Ur Z, Khan S, Shah Mohammad t, Brusseau ML, Khan SA, Mainhagu J. 2017. Transfer of heavy metal from soil to vegetables and associated human health risk in selected sites in Pakistan; Pedosphere. 1002-0160: (32) 1315.

DOI: https://doi.org/10.1016/S1002-0160 (17)60440-5

$\checkmark$ Sathawara NG, Parich DJ, Agrawal YK. 2004. Essential heavy metal in environmental samples from western India, Bulletin of Environmental Contamination. Toxicology. 73, 264-269. DOI: https://doi.org/10.1007/s00128-004-0490-1

$\checkmark$ Säumel I, Kotsyuk I, Holscher M, Lenkereit C, Weber F, Kowarik I. 2016. How healthy is urban horticulture in high traffic areas? Trace metal concentration in vegetable crops from planting within inner city neighborhood in Berlin, Germany. Environmental Pollution. 165, 124-132.

DOI: https://doi.org/10.1016/j.envpol.2012.02.019

$\checkmark$ Shaheen N, Md. Irfan N, Khan I.N, Saiful I, Md. Saiful I, Md. Kaswer A. 2016. Presence of heavy metals in fruits and vegetables: Health risk implications in Bangladesh. Chemosphere. 152: 431-438.

DOI: https://doi.org/10.1016/j.chemosphere.2016.02.060

$\checkmark$ Singh A, Sharma RK, Agrawal M, Marshell FM. 2010. Risk assessment of heavy metal toxicity through contaminated vegetables from waste water irrigated area of Varanasi, India. Tropical Ecology. 51(25), 375-387.

DOI: http://www.tropecol.com/pdf/open/PDF_51_2S/J-09.pdf

$\checkmark$ Stevanovic V, Gulan L, Milenkovic B, Valjarevic A, Zeremski T, Penjisevic I. 2018. Environmental risk assessment of radioactivity and heavy metal in soil of toplica region, South Serbia. Environmental Geochemistry Health.

DOI: http://doi.org/10.1007/s10653-018-0085-0

$\checkmark$ Waqas M, Li G, Khan S, Shamshad I, Reid BJ, Qamar, Z, Chao C. 2015. Application of sewage sludge and sewage sludge biochar to reduce polycyclic aromatic hydrocarbons (PAH) and potentially toxic elements (PTE) accumulation in tomato; Environmental Science and pollution research. 22:7071-7081. 
DOI: https://doi.org/10.1007/s11356-015-4432-8

$\checkmark$ Wang M, Liu R, Lu X, Zhu Z, Wang H, Jiang, Liu J, Wu Z. 2018. Heavy metal contamination and ecological risk assessment of swine manure irrigated vegetable soils in Jiangxi Province, China. Bulletin of Environmental Contamination and Toxicology. 100:634-640. DOI: https://doi.org/10.1007/s00128-018-2315-7

$\checkmark$ USEPA (US Environmental Protection Agency). 2015. Risk based screening table. Composite table: summary Table 0615. Accessible at http://www2.epa.gov/risk/riskbasedscreeningtablegenerictables.

$\checkmark$ Yang J, Guo H, Ma Y, Wang L, Wei D, Hua L. 2010. Genotype variation in the accumulation of $\mathrm{Cd}$ exhibited by different vegetables, Journal of Environmental Science China. 22, 1246-1252. DOI: https://doi.org/10.1016/s1001-0742(09)60245-X

$\checkmark$ Zhaoyong Z, Xiaodong Y, Simay Z, Mohammed A. 2018. Health risk evaluation of heavy metals in green land soils from urban parks in Urumqi, Northwest China. Environmental Science and Pollution Research. 25, 4459-4473.

DOI: http://doi.org/10.1007/s11356-017-0737-0

$\checkmark$ Zheng F, Wei W, Li M, Huang R, Yang F, Duan Y. 2015. Heavy Metal contamination in rice-producing soils of Hunan Province, China and potential health risk. International Journal of Environmental Research and Public Health. 12, 15584-15593.

DOI: https://dx.doi.org/10.3390/ijerph121215005

$\checkmark$ Zhiyuan WEI, Dengfeng W, Huiping Z, Zhiping QI. 2011. Assessment of soil Heavy Metals pollution with principal component analysis and geoaccumulation index. Procedia Environmental Sciences. 10: 1946-1952.

DOI: https://doi.org/10.1016/j.proenv.2011.09.305

$\checkmark$ Zhou H, Yang WT, Zhou X, Liu L, Gu JF, Wang WL, Zou JL, Tian T, Peng PQ, Liao BH. 2016. Accumulation of Heavy Metals in Vegetable Species Planted in Contaminated Soils and the Health Risk Assessment. International Journal of Environmental Research and Public Health. 13, 289.

DOI: https://doi.org/10.3390/ijerph13030289

$\checkmark$ Zwolak A, Sarzynska M, Szpyrka E, Stawarczyk K. 2019. Source of soil pollution by heavy metals and their accumulation in vegetables: A Review. Water Air Soil Pollution. 230:164. DOI: https://doi.org/10.1007/s11270-019-4221-y 


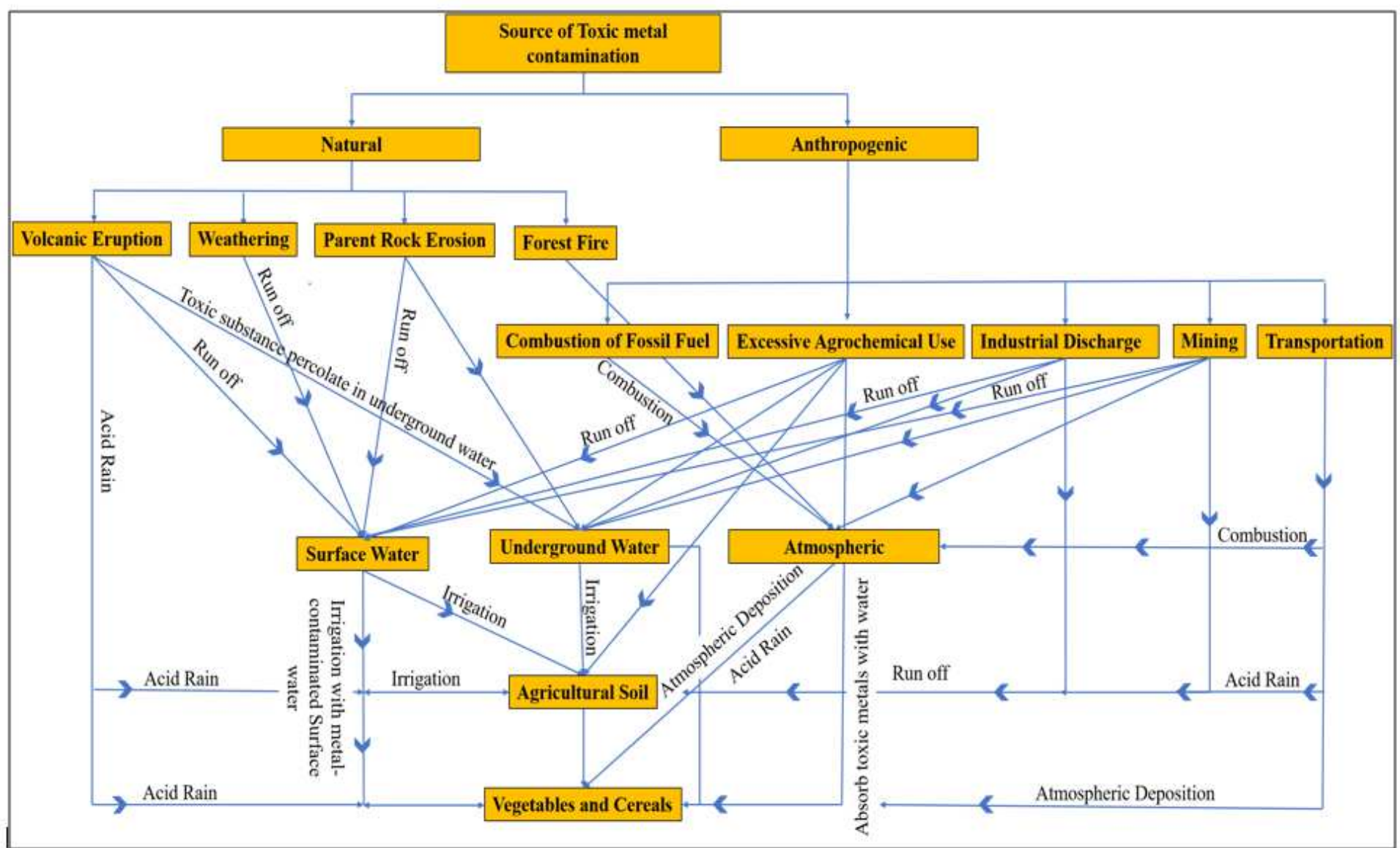

\section{Figure 1}

Direct or indirect pathway of Toxic Heavy metals (THMs) contamination in vegetables and cereals by a different source of toxic metal contamination. 

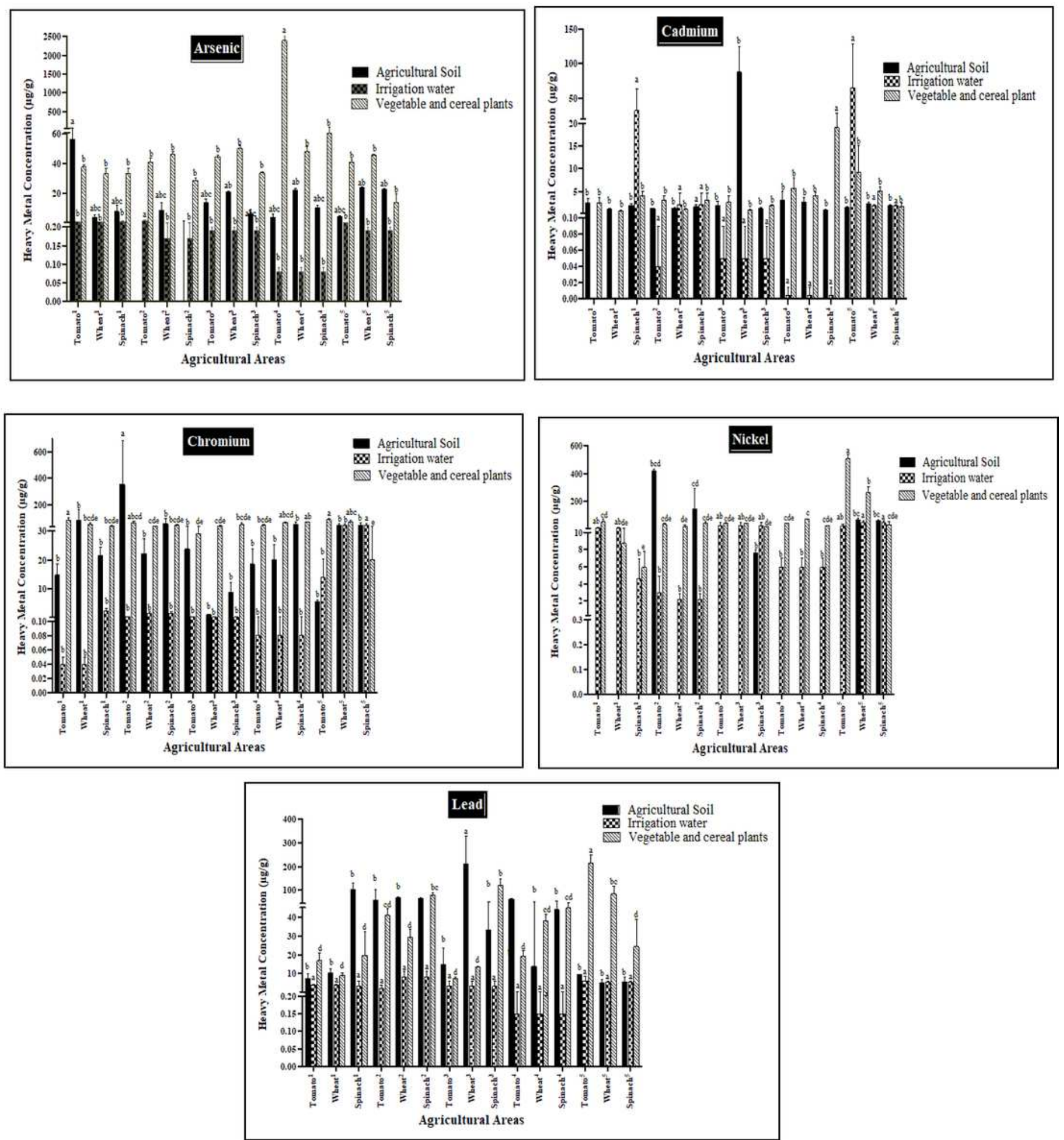

Figure 2

Average THMs concentration in different agriculture soil, irrigation water, vegetable and cereal plants samples collected from different pre-urban agriculture areas around Lucknow city, India. The data represent mean \pm standard error, Small alphabets in a graph show significant difference in heavy metal concentration in irrigation water at temporal scale at $p<0.05$. Numbering on $X$-axis shows the sampling area i.e., 1) Biswan; 2) Khairabaad; 3) Shindholi;4) Pasonda and 5) Mohanlal Ganj. 

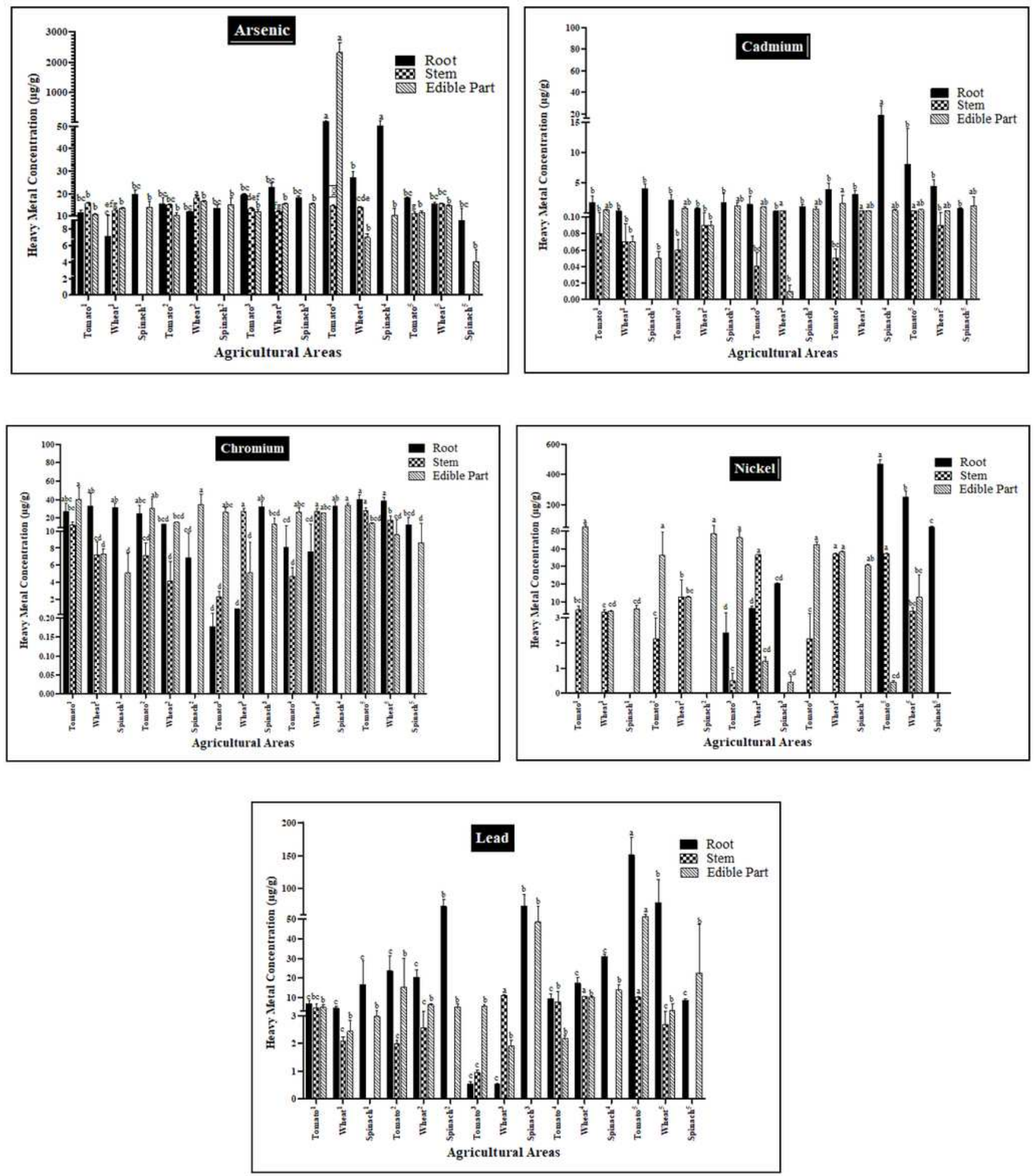

\section{Figure 3}

Average THMs concentration in different parts (root, stem, and edible parts) of vegetable and cereals plants samples collected from different pre-urban agriculture areas around Lucknow city, India. The data represent mean \pm standard error, Small alphabets in a graph show significant difference in heavy metal concentration in irrigation water at temporal scale at $p<0.05$. Numbering on $X$-axis shows the sampling area i.e., 1) Biswan; 2) Khairabaad; 3) Shindholi; 4) Pasonda and 5) Mohanlal Ganj. 